\title{
ЗАСТОСУВАННЯ ЕКСПЕРТНИХ ОЦІНОК ДЛЯ АНАЛІЗУ СИСТЕМИ ПРОФІЛАКТИКИ АТРОФІЇ ЗОРОВИХ НЕРВІВ
}

\author{
ДУ «Інститут нейрохірургії ім. А.П. Ромоданова НАМН України», м. Київ
}

\begin{abstract}
Мета: створення програми профілактики атрофії зорових нервів різного ґенезу та проведення її експертної оцінки.

Матеріали і методи. У дослідженні використовувалися метод системного підходу, аналітико-синтетичний метод, результати власних досліджень, метод експертних оцінок.

Результати. Розроблена програма профілактики атрофії зорових нервів різного ґенезу та проведена експертна оцінка даної моделі.

Висновки. Переважно високі бальні експертні оцінки дозволяють зробити висновок про актуальність даної моделі, доцільність її впровадження у практику охорони здоров'я та прогностичну ефективність.
\end{abstract}

КЛЮЧОВІ СЛОВА: зоровий нерв, атрофія, профілактика, експертні оцінки.

Офтальмологічна галузь знаходиться у процесі реформування, основною метою якого є забезпечення населення доступною та якісною офтальмологічною допомогою, зниження рівня сліпоти та слабко бачення [8]. Особливе місце серед офтальмологічних захворювань займає атрофія зорових нервів (АЗН) [7;11]. Дана патологія однаково цікавить офтальмологів, неврологів, нейрохірургів. Атрофія зорових нервів обумовлює близько 20\% сліпоти серед іншої офтальмопатології, 60\% хворих є інвалідами I та II груп. В Україні частота АЗН у структурі первинної інвалідності по зору складає 13,3\% [1;3;4;5]. Послаблений зір та сліпота негативно впливають на якість життя хворих, оскільки саме через зоровий аналізатор людина отримує близько 80\% інформації про навколишній світ [9;10]. Знижений зір перешкоджає людині брати активну участь у житті суспільства, у праці на виробництві $[2,6]$. Дана проблема негативно впливає на економіку країни в цілому.

Медична допомога хворим з АЗН має ряд недоліків та проблем:

1. Головною та найбільш серйозною проблемою є пізнє виявлення низхідної АЗН, коли ще відсутні зміни очного дна, тобто АЗН не «спустилась» до диску зорового нерва. Основні помилки у діагностиці та веденні хворих спостерігаються саме у даного контингенту хворих.

2. Раннє виявлення та адекватне лікування захворювань, що призводять до розвитку АЗН. Атрофічний процес може виникати у результаті набряку, дегенерації, пошкодження зорового нерва. Варіабельність етіологічних факторів, як офтальмологічних, так і неофтальмологічних, робить виявлення даної патології досить складною задачею.

(C) В.А. Васюта, 2015
3. Атрофія зорових нервів є поліетіологічним захворюванням і потребує консультацій і лікування у різних фахівців - кардіолога, ревматолога, інфекціоніста, отоларинголога, невропатолога тощо. На жаль, міждисциплінарний підхід до даної проблеми проводиться не в повній мірі. Необхідно знайти шляхи взаємодії між лікарями різних спеціальностей у вирішенні проблеми АЗН.

4. За нашими даними, не всім хворим з підозрою на АЗН проводиться периметричне дослідження, що є грубою діагностичною помилкою.

5. Не існує чіткого покрокового протоколу діагностики АЗН для діагностики як висхідної, так і низхідної АЗН.

6. Немає чіткої тактики лікування АЗН нейрохірургічного профілю.

7. Не здійснюється ретельний контроль над факторами ризику, що призводять до виникнення АЗН.

Метою дослідження було створення програми профілактики АЗН різного ґенезу та проведення експертної оцінки даної програми фахівцямиофтальмологами.

Матеріали і методи. У дослідженні використовувалися метод системного підходу, аналітикосинтетичний метод, результати власних досліджень, метод експертних оцінок.

Результати дослідження та їх обговорення. Нами створена Програма профілактики АЗН різного ґенезу, яка складається з наступних компонентів: 1) створена модель управління системою надання медичної допомоги хворим з АЗН на регіональному рівні для оптимізації та удосконалення системи раннього виявлення хворих 3 АЗН різного ґенезу (табл. 1); 2) запропонована трирівнева система профілактики АЗН різного ґенезу на кожному рівні надання офтальмологічної допомоги; 3) створений покроковий протокол для діагностики АЗН; 4) створений 
протокол лікування хворих з АЗН; 5) обгрунтовано створення нейроофтальмологічних кабінетів для ранньої діагностики, лікування та диспансерного нагляду за хворими з АЗН.

Таблиця 1. Організаційно-функціональні елементи управління системою медичної допомоги Хворим з АЗН на регіональному рівні

\begin{tabular}{|c|c|c|c|}
\hline Організаційно-правовий & $\begin{array}{c}\text { Структурно- } \\
\text { функціональний }\end{array}$ & $\begin{array}{l}\text { Ресурсно- } \\
\text { економічний }\end{array}$ & $\begin{array}{c}\text { Соціально- } \\
\text { екологічні } \\
\text { умови }\end{array}$ \\
\hline $\begin{array}{c}\text { Державні законодавчі акти } \\
\text { України в галузі охорони } \\
\text { здоров’я та соціального захисту } \\
\text { населення }\end{array}$ & $\begin{array}{c}\text { Визначення оптимальної } \\
\text { мережі медичних закладів } \\
\text { для забезпечення } \\
\text { наступності діагностично- } \\
\text { лікувального процесу АЗН }\end{array}$ & $\begin{array}{c}\text { Інтенсивний принцип } \\
\text { оптимізації } \\
\text { офтальмологічної } \\
\text { допомоги при АЗН }\end{array}$ & $\begin{array}{c}\text { Стан здоров’я } \\
\text { населення регіону }\end{array}$ \\
\hline $\begin{array}{c}\text { Накази МОЗ України «Про } \\
\text { систему офтальмологічної } \\
\text { допомоги населенню України», } \\
\text { «Про затвердження протоколів } \\
\text { надання медичної допомоги за } \\
\text { спеціальністю «Офтальмологія» } \\
\text { та інших спеціальностей» }\end{array}$ & $\begin{array}{c}\text { Обгрунтування } \\
\text { структурно-функціональної } \\
\text { моделі діяльності } \\
\text { нейроофтальмологічних } \\
\text { кабінетів }\end{array}$ & $\begin{array}{c}\text { Визначення } \\
\text { економічної доцільності } \\
\text { надання окремих видів } \\
\text { та форм медичної } \\
\text { допомоги при АЗН }\end{array}$ & $\begin{array}{c}\text { Соціально- } \\
\text { демографічний } \\
\text { склад населення }\end{array}$ \\
\hline $\begin{array}{c}\text { Визначення статусу та функцій } \\
\text { амбулаторних та стаціонарних } \\
\text { медичних закладів, } \\
\text { спеціалізованих } \\
\text { офтальмологічних центрів }\end{array}$ & $\begin{array}{c}\text { Планування обсягів } \\
\text { офтальмологічної } \\
\text { допомоги на підставі } \\
\text { даних про здоров’я } \\
\text { населення та поширеності } \\
\text { факторів ризику }\end{array}$ & $\begin{array}{c}\text { Удосконалення } \\
\text { матеріально-технічного } \\
\text { забезпечення та } \\
\text { використання ресурсів } \\
\text { лікувально- } \\
\text { діагностичного процесу }\end{array}$ & $\begin{array}{l}\text { Рівень та спосіб } \\
\text { життя населення }\end{array}$ \\
\hline $\begin{array}{c}\text { Функціональна взаємодія } \\
\text { спеціалізованих державних та } \\
\text { приватних офтальмологічних } \\
\text { закладів, регіональних } \\
\text { багатопрофільних медичних } \\
\text { закладів }\end{array}$ & $\begin{array}{c}\text { Планування обсягів та } \\
\text { структури спеціалізованої } \\
\text { неофтальмологічної } \\
\text { допомоги для хворих } 3 \\
\text { АЗН }\end{array}$ & $\begin{array}{c}\text { Функціональна } \\
\text { інтеграція } \\
\text { нейроофтальмологічної } \\
\text { допомоги }\end{array}$ & $\begin{array}{c}\text { Екологічні умови } \\
\text { у регіоні }\end{array}$ \\
\hline $\begin{array}{c}\text { Інтеграційний принцип } \\
\text { лікувально-діагностичного } \\
\text { процесу для забезпечення } \\
\text { оптимальної взаємодії, } \\
\text { послідовності та управління } \\
\text { системою медичної допомоги } \\
\text { хворим з АЗН }\end{array}$ & $\begin{array}{c}\text { Планування потреби } \\
\text { медичної допомоги хворим } \\
\text { з АЗН на різних рівнях іï } \\
\text { надання }\end{array}$ & $\begin{array}{c}\text { Удосконалення } \\
\text { кадрового забезпечення } \\
\text { нейроофтальмологічної } \\
\text { допомоги }\end{array}$ & $\begin{array}{c}\text { Економічний } \\
\text { розвиток регіону } \\
\text { та рівень } \\
\text { соціального } \\
\text { благополуччя } \\
\text { населення }\end{array}$ \\
\hline
\end{tabular}

Для оцінки ефективності запропонованої програми проведені експертні оцінки серед офтальмологів, що мають практичний досвід в організації охорони здоров'я та безпосередньо задіяні у лікувально-діагностичному процесі та за функціональними обов'язками пов'язані з організацією лікувально-діагностичного процесу (завідувачі офтальмологічними відділеннями, головні лікарі та їх заступники з лікувальної роботи спеціалізованих офтальмологічних медичних закладів, головні спеціалісти). Всього отримано відповіді від 32 залучених експертів.

За рівнем кваліфікації усі фахівці мали вищу кваліфікаційну категорію, три доктори та 9 кандидатів медичних наук. Експертна оцінка проводилась за етапним принципом. Після формування переліку параметрів моделі була проведена їх експертна оцінка на предмет доцільності вклю- чення в аналіз. Надалі кожен з 32 експертів виставляв персоніфіковані оцінки за окремими параметрами. Варіабельність оцінок була основою для визначення ступеня узгодженості думок експертів. Узагальнена оцінка результатів за основними аспектами оптимізації наведена у таблиці 2.

Деталізована характеристика оцінок має наступний вигляд. За параметром «Обґрунтування доцільності реалізації системи профілактики АЗН на первинному, вторинному та третинному рівнях» оцінку 8 балів виставили $6(18,75 \%)$ експертів, 9 балів - 20 (62,5\%), 10 балів - 6 (18,75\%),

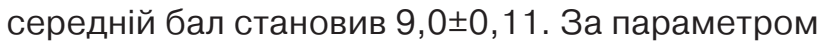
«Обґрунтування створення спеціалізованих нейроофтальмологічних кабінетів» оцінку 8 балів виставили $9(28,1 \%), 9$ балів - $10(31,3 \%), 10$ балів - 13 (40,6\%) фахівців, середній бал стано-

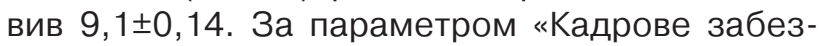


Таблиця 2. Експертні оцінки основних аспектів оптимізації системи профілактики та організаційно-функціональної моделі медичної допомоги хворим з АЗН

\begin{tabular}{|l|c|c|}
\hline \multicolumn{1}{|c|}{ Елемент експертної оцінки } & $\begin{array}{c}\text { Бальна } \\
\text { оцінка } \\
\mathrm{X} \pm \mathrm{m}\end{array}$ & $\begin{array}{c}\text { Варіабельність } \\
\text { оцінок } \\
\text { (Сv, \%) }\end{array}$ \\
\hline $\begin{array}{l}\text { Обгрунтування доцільності реалізації системи профілактики АЗН на } \\
\text { первинному, вторинному та третинному рівнях }\end{array}$ & $9,0 \pm 0,11$ & 6,9 \\
\hline $\begin{array}{l}\text { Iнтенсивний принцип оптимізації офтальмологічної допомоги - } \\
\text { обгрунтування створення спеціалізованих нейроофтальмологічних кабінетів }\end{array}$ & $9,1 \pm 0,14$ & 9,1 \\
\hline Кадрове забезпечення нейроофтальмологічної допомоги & $9,1 \pm 0,13$ & 8,1 \\
\hline Сучасне технічне оснащення нейроофтальмологічних кабінетів & $8,9 \pm 0,12$ & 7,4 \\
\hline Оптимізація діагностичних алгоритмів та технологій & $9,0 \pm 0,14$ & 9,2 \\
\hline $\begin{array}{l}\text { Оптимізація алгоритмів спеціалізованої неофтальмологічної консультативної } \\
\text { допомоги на різних рівнях та міжффахова взаємодія }\end{array}$ & $9,1 \pm 0,11$ & 7,2 \\
\hline $\begin{array}{l}\text { Інформаційне забезпечення лікувально-діагностичного та консультативного } \\
\text { процесу при АЗН }\end{array}$ & $9,0 \pm 0,12$ & 7,6 \\
\hline $\begin{array}{l}\text { Обгрунтування нормативів штатного розпису нейроофтальмологічних } \\
\text { кабінетів }\end{array}$ & $8,9 \pm 0,15$ & 9,3 \\
\hline $\begin{array}{l}\text { Оптимізація витрат робочого часу за окремими елементами лікувально- } \\
\text { діагностичного процесу }\end{array}$ & $9,0 \pm 0,13$ & 8,4 \\
\hline $\begin{array}{l}\text { Оптимізація алгоритмів диспансерного спостереження на різних рівнях } \\
\text { медичної допомоги для хворих з АЗН }\end{array}$ & $9,0 \pm 0,12$ & 8,0 \\
\hline
\end{tabular}

печення нейроофтальмологічної допомоги» 8 балів поставили 7 (21,8\%), 9 балів - 15 (46,9\%), 10 балів - $10(31,3 \%)$ експертів, середній бал

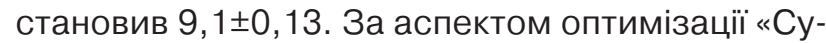
часне технічне оснащення нейроофтальмологічних кабінетів» оцінку 8 балів поставили 8 (25,0\%), 9 балів - 18 (56,2\%), 10 балів - 6 (18,8\%) екс-

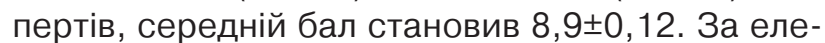
ментом «Оптимізація діагностичних алгоритмів та технологій» оцінку 8 балів поставили 11 $(34,4 \%), 9$ балів - 11 (34,4\%), 10 балів - 10 $(31,2 \%)$ експертів, середній бал становив $9,0 \pm 0,14$. За елементом «Оптимізація алгоритмів спеціалізованої неофтальмологічної консультативної допомоги на різних рівнях та міжфахова взаємодія» оцінку 8 балів поставили 5 (15,7\%), 9 балів - 18 (56,2\%), 10 балів - 9 (28,1\%) екс-

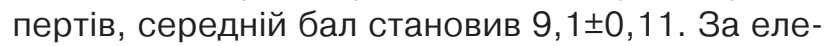
ментом «Інформаційне забезпечення лікувальнодіагностичного та консультативного процесу при АЗН» оцінку 8 балів поставили 7 (21,9\%), 9 балів 17 (53,1\%), 10 балів - 8 (25,0\%) експертів, се-

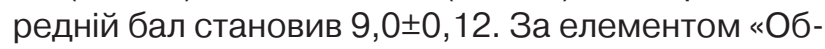
ґрунтування нормативів штатного розпису нейроофтальмологічних кабінетів» оцінку 8 балів поставили 12 (37,5\%), 9 балів - 10 (31,25\%), 10 балів - 10 (31,25\%) експертів, середній бал

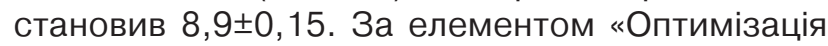
витрат робочого часу за окремими елементами лікувально-діагностичного процесу» оцінку 8 балів поставили 8 (25,0\%), 9 балів - 14 (43,8\%), 10 балів - 10 (31,2\%) експертів, середній бал становив 9,0 0,13 . За аспектом «Оптимізація алгоритмів диспансерного спостереження на різних рівнях медичної допомоги» оцінку 8 балів поставили 8 (25,0\%), 9 балів - 16 (50,0\%), 10 балів - 8 (25,0\%)

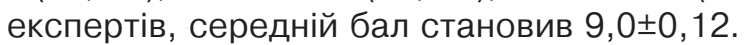

Варіабельність основних складових елементів оптимізації оцінки системи профілактики та організаційно-функціональної моделі медичної допомоги хворим з АЗН має низький рівень 6,99,3\%, що свідчить про типовість оцінок експертів за даними аспектами. Узгодженість думок експертів за основними елементами, що характеризують досліджувану модель, підтверджує статистично значущий рівень коефіцієнта конкордації (W=0,82, p=0,007).

Аналіз окремих елементів експертної оцінки системи профілактики та організаційно-функціональної моделі медичної допомоги хворим з АЗН дозволяє зробити висновок про актуальність даної моделі, доцільність її впровадження в практику охорони здоров'я та прогностичну ефективність. Переважаючі високі бальні експертні оцінки за окремими складовими елементами функціональної моделі показують пріоритетні напрями ії реалізації з урахуванням медико-соціальних регіональних особливостей для забезпечення максимальної клінічної та організаційної ефективності. 


\section{Список літератури}

1. Абрамова Л. П. Особенности организации медико-психологической помощи инвалидам по зрению пребывающим в лечебно-профилактическом учреждении широкого профиля / Л. П. Абрамова, В. А. Момот // Мед. реабилитация. - 2005. - № 2. - С. 26-27.

2. Густов А. В. Практическая нейроофтальмология : в 2 т. / А. В. Густов, К. И. Сигрианский, Ж. П. Столярова. 2-е изд. - Н. Новгород : НГМА, 2003. -. Т. 1. - 2003. - 260 с.

3. Інвалідність унаслідок патології органа зору / Т. А. Аліфанова, О. Л. Чуйко, А. М. Логінова [та ін.] // Основні показники інвалідності та діяльності медико-соціальних експертних комісій України за 2013 рік : аналіт.-інформ. дов. / С. І. Черняк, А. В. Іпатов [та ін.] ; МОЗ України, Від. мед.-соц. Експертизи ; Укр. держ. НДІ мед.-соц. пробл. інвалідності МОЗ України. - Дніпропетровськ : Акцент ПП, 2014. - С. 39-44.

4. Калеева Э. В. Инвалидность вследствие болезней глаза в Российской Федерации, медико-социальные аспекты экспертизы и реабилитации при офтальмопатологии : автореф. дис. ... канд. мед. наук : 14.02 .06 / Э. В. Калеева. - М., 2010. - 29 с.

5. Касимов Э. М. Гендерные особенности медико-социального груза инвалидности вследствие офтальмопатологии / Э. М. Касимов, Н. М. Рустамова // Офтальмология. - 2011. - № 1. - С. 49-51.

6. Никифоров А. С. Офтальмоневрология / А. С. Никифоров, М. Р. Гусева. - М. : ГЭОТАР-Медиа, $2014 .-647$ с.

7. Нисан Б. А. Международные аспекты организации профилактики нарушений зрения как социально значимой патологии / Б. А. Нисан // Глаз. - 2012. - № 5. - С. 20-21.

8. Організація офтальмологічної допомоги на сучасному етапі : довідник лікаря / за ред. С.О. Рикова. - К. : Доктор медіа, 2008. - 357 с.

9. Разумовский М. И. Оценка зрительных возможностей в трудовом процессе инвалидов по зрению / М. И. Разумовский, А. М. Разумовская // Офтальмология. - 2014. - № 1. - С. 58-61.

10. Рустамова Н. М. Сравнительная оценка возраста лиц, впервые признанных инвалидами по различным заболеваниям глаз / Н. М. Рустамова // Офтальмология. - 2012. - № 1. - С. 80-82.

11. Golnik K. C. Neuro-ophthalmology around the world / K. C. Golnik // J. Neuroophthalmol. - 2013. - Vol. 33, № 4. P. 319-321.

\section{ИСПОЛЬЗОВАНИЕ ЭКСПЕРТНЫХ ОЦЕНОК ДЛЯ АНАЛИЗА ПРЕДЛОЖЕННОЙ СИСТЕМЫ ПРОФИЛАКТИКИ АТРОФИИ ЗРИТЕЛЬНЫХ НЕРВОВ}

B.A. Васюта

ГУ «Институт нейрохирургии им. А.П. Ромоданова НАМН Украины», г. Киев

Цель: создание программы профилактики атрофии зрительных нервов различного генеза и проведение ее экспертной оценки.

Материалы и методы. В исследовании использовались метод системного подхода, аналитикосинтетический метод, результаты собственных исследований, метод экспертных оценок.

Результаты. Разработана Программа профилактики атрофии зрительных нервов разного генеза и проведена экспертная оценка данной модели.

Выводы. Преимущественно высокие бальные экспертные оценки позволяют сделать вывод об актуальности данной модели, целесообразности ее внедрения в практику здравоохранения и прогностической эффективности.

КЛЮЧЕВЫЕ СЛОВА: зрительный нерв, атрофия, профилактика, экспертные оценки.

\section{APPLICATION OF EXPERT ASSESSMENTS FOR ANALYSIS OF PROPOSED SYSTEM FOR THE PREVENTION OF OPTIC NERVE ATROPHY}

V.A. Vasyuta

SI "Institute of Neurosurgery named after A.P. Romodanov NAMS of Ukraine", Kyiv

Purpose: creation of prophylactic programs of ONA various genesis and carrying out its expert estimation.

Materials and methods. In study method of systematic approach, analytic-synthetic method, results of own researches, the method of expert evaluations were used.

The Results. The prophylactic program of ONA verious genesis is developed and expert evaluation of the model has been spent.

Conclusions. Mainly highball expert estimations allow to draw conclusion about relevance of this model, feasibility of its implementation in public health practice and predictive efficiency.

KEY WORDS: optic nerve, atrophy, prevention, expert evaluation.

Рукопис надійшов до редакції 10.03.2015

Відомості про автора:

Васюта Віра Анатоліївна - к.мед. н., лікар-нейроофтальмолог Ду «Інститут нейрохірургії ім. А.П. Ромоданова НАМН України»; тел.: 0667196830. 